\title{
THE INTENSITY OF THE EXPRESSION OF MOBBING IN EMPLOYEES' RELATIONS AT LITHUANIAN ORGANIZATIONS
}

\author{
Jolita Vveinhardt, Dalia Štreimikienè
}

\section{Introduction}

Observations of animal behaviour show the natural origin of mobbing phenomenon, which later has been compared with people behaviour, which later acquires rather sophisticated forms within people communities. Leymann [22] defined mobbing as specific conflict existing in organizations; the following three main criteria are characteristic for it: attack, attack intensity, attack duration. Mobbing is the phenomenon covering social relations, which influenced by socio-economic and cultural consistent patterns of society development. This is proved both by the researches performed some time ago and new researches. The society of Lithuania, which restored its independence in the beginning of the last decade of the 20th century, as well as most developing countries of the post-Soviet bloc experienced and are still experiencing economic, social and managerial culture transformations. The mobbing term is still new, it sounds 'exotically' enough for the society; however the researches being performed in the country have shown deep problems of organizations' management, which provoke mobbing conflicts. The main conflict takes place not in the level of employees' relations but in the planes of interrelationship and management culture, which are significantly influenced by national traditions.

Research relevance is as follows. Having analyzed modern researches, the following main accents, which should be surveyed deeper, become evident. So far it has not been clearly answered what influence the gender aspect makes upon the phenomenon's fixation; though the researches show that women accept mobbing much more frequently and more intense than men ([43], [44], [40], [41], [8], [34], etc.). Mobbing is analyzed as economic problem ([26], [6], [25], [20], [14], [33], etc.). Socio-cultural as well as society's social and economic development aspects remain important, especially for developing countries where mobbing actions are not always understood adequately because reactions to aggressor's behaviour differ. These differences have been confirmed by the researches performed in different cultures recently ([1], [45], [8], [32], etc.). Undoubtedly, relations between employees, their quality are an integral part of such components as evaluation of employees [18], the stress they experience [31], etc. l.e., it is especially important to maintain the balance between various external and internal interferences, without creating favourable conditions for the development of destructive relations between the employees.

The research performed in Turkey [1] shows the danger, which is caused by sociocultural particularity. The conclusion that the respondents answered insincerely was made. The outcomes of the research performed in Estonia [32] confirm socio-cultural dangers, which can cause certain error in similar researches. In addition, the cohesion between mobbing and physical environment, the meaning of managerial culture, which is related to unfavourable climate of the organization, has been confirmed ([29], [1], [37], [21], etc.). In Lithuania mobbing is most frequently analyzed as ethical problem ([39], [38]), functional outcomes of psychological terror for a body are emphasized ([17], [24], [30], etc.). Bultena [4] points out that mobbing is evident more in private than in public sector. However, more comprehensive researches, which would compare public and private sectors of Lithuania as post-Soviet developing country, are missing, especially in emphasizing managerial context of the problem.

In this article, there were set following hypothesis: "The expression of mobbing in Lithuanian organizations as management problem is more intensive in the sector of private activity." This hypothesis is based on 
the researches performed in 2009-2015. The research was performed during economic recession when interpersonal relations were more intensively stimulated by internal and external reasons. Having evaluated sociocultural context, the intensity of mobbing should be evident when the country overcomes the economic recession.

In this research the context of developing countries is purposely stressed as Lithuania as well as most post-Soviet countries experience not only economic but also social, mental transformations, which influence the cohesion of mobbing as specific harassment with organization's climate. Having estimated the influence of culture upon mobbing expression, the research performed in Lithuania can serve for deeper understanding of the phenomenon to develop, apply preventive and intervention mechanisms.

The research problem is formed by the following questions: what mobbing expression is in organizations of different sector and how the applied instrument diagnoses the expression intensity of mobbing in employees' relations.

In the world the researches on mobbing have been performed for a long time and the circle of researchers is large enough ([22], [23], [26], [43], [42], [4], [1], [12], [7], [28], [35], [36], [10], [11], [2], [3], [5], [8], [9], [13], [15], [16], [27], [32], [34], [37], [19], etc.).

In Lithuania the researches on mobbing in employees' relations have just been started, the researches have been performed more intensely during the last decade ([17], [39], [24], [30], [38], [44], [45], etc.).

There were used following research methods. Analysis and synthesis of literature, survey-in-written. MDS (Multidimensional Scaling). MDS analysis provided some additional scientific information. This method revealed the latent expression of the analysed phenomenon. Multidimensional Scaling method is also known as a cognitive map, because it reflects individual and subjective representations of the analyzed phenomenon. MDS model reveals statistically pure and theoretically significant complex structure of the analysed features. MDS model is analysed by assessing the vertical and horizontal axes separately. Multidimensional scaling method is intended to represent the objects in lowdimensional space, when objects are defined by similarities/ dissimilarities, and the distances in image space represent dissimilarities. Multidimensional Scaling methods are designed as procedures of minimizing the representation accuracy criterion. Using the multidimensional scaling model two dimensions - z-estimate and variation range - were set; precedence and expression profile dimensions were addressed. The results of the research are reflected in a typical graph of MDS axes. This map of organisations of various areas of professional activity illustrates the relatively high and relatively low expression of mobbing in organisations. The levels of expression of mobbing, the organisations in certain areas of activity on the initial phase and those which reached the critical level are highlighted.

\section{Research Methodology}

The questionnaire presented in this paper consists of 21 questions and 47 items (Likert's scale), which were aimed to identify what character of sneering the mobbing victims had experienced.

The items of Leymann [22] make the basis of the items distinguished in the questionnaire (Scales 1-3). They are constructed by transforming (in linguistic sense) the items of $H$. Leymann presented in the LIPT inventory and formulating them in the first person. The items (in the original questionnaire's variant in Lithuanian) have been adapted for specific cultural environment).

Out of 21 questions - 10 questions are of demographic character in order to form as vivid as possible portrait of a mobbing victim. Other 11 questions were aimed to find out harassment duration and frequency, a discriminator (a colleague, manager and so on), the reaction of the victim to harassment, the person who lent assistance, the means to stop harassment, outcomes against the discriminator and so on.

By means of concepts' operationalization three scales of the instrument have been formed: Communication interferences in employees' relations; Formation of negative opinion and work character, Employees' physical state and outcomes.

The first scale Communication interferences in employees' relations consists of subscales of communication and isolation. The second scale Formation of negative opinion and work character consists of subscales of reputation and tasks. The third scale Employees' physical state 
and outcomes consists of subscales of health and harm. The subscales embrace 47 items (communication -11 , isolation -5 , reputation 15 , tasks -8 , health -5 , harm -3 items).

The culture, in which the instrument has been checked, distinguishes in the social historical experience (determined by the Soviet social engineering relevant for Central and Eastern Europe. Initiatives, perception of public decisions, publicity danger, reticence, which despite political and social transformations taking place remain important socio-cultural factors that influence different researches being performed, are characteristic. In pursuing for precision the control questions that aim to evaluate openness of the respondents have been included into the questionnaire.

It is known from researches and practices of psychometrics that the test (diagnostic construct) can be successfully applied only when it meets certain qualities: first of all, reliability and validity. These characteristics are detected after having performed special research and psychometric calculations. The above mentioned psychometric characteristics can be high enough (see Tab. 1).

\begin{tabular}{|c|c|c|c|c|c|c|c|c|c|c|}
\hline Tab. 1: & $\begin{array}{l}\text { aracte } \\
\text { erferer }\end{array}$ & $\begin{array}{l}\text { istics of } \\
\text { ces in em }\end{array}$ & $\begin{array}{l}\text { limensio } \\
\text { ployees' }\end{array}$ & $\begin{array}{l}\text { s' method } \\
\text { elationsh }\end{array}$ & ologic & qual & of $\mathrm{cc}$ & nmur & ation & \\
\hline \multirow[t]{2}{*}{ Subscales } & \multirow{2}{*}{$\begin{array}{c}\mathrm{N} \\
\text { items }\end{array}$} & \multirow{2}{*}{$\begin{array}{c}\text { Explained } \\
\text { dispersi- } \\
\text { on } \%\end{array}$} & \multirow{2}{*}{$\begin{array}{c}\text { Cronbach } \\
\text { alpha }\end{array}$} & \multirow{2}{*}{$\begin{array}{l}\text { Spearman- } \\
\text {-Brown }\end{array}$} & \multicolumn{3}{|c|}{ Factorial weight (L) } & \multicolumn{3}{|c|}{$\begin{array}{c}\text { Correlation of whole } \\
\text { unit (r/itt) }\end{array}$} \\
\hline & & & & & mean & $\min$ & $\max$ & mean & $\min$ & $\max$ \\
\hline Communication & 11 & 36.12 & 0.85 & 0.79 & 0.59 & 0.41 & 0.78 & 0.34 & 0.06 & 0.86 \\
\hline Isolation & 5 & 59.17 & 0.89 & 0.88 & 0.77 & 0.67 & 0.81 & 0.58 & 0.25 & 0.82 \\
\hline Reputation & 15 & 37.36 & 0.89 & 0.86 & 0.60 & 0.36 & 0.73 & 0.35 & 0.03 & 0.76 \\
\hline Tasks & 8 & 46.05 & 0.88 & 0.78 & 0.68 & 0.58 & 0.79 & 0.45 & 0.08 & 0.82 \\
\hline Health & 5 & 44.90 & 0.83 & 0.81 & 0.65 & 0.38 & 0.81 & 0.41 & 0.09 & 0.79 \\
\hline Harm & 3 & 60.54 & 0.85 & - & 0.77 & 0.67 & 0.83 & 0.58 & 0.32 & 0.86 \\
\hline
\end{tabular}

Source: own

The questionnaire was installed in the website http://www.mobingas.lt administrated by the article's author J. Vveinhardt. The website Mobingas.It presents the information about the mobbing concept, reasons, outcomes and intervention. It presents scientific and journalistic articles of the author about mobbing phenomenon; the results of the previous researches are discussed. The data were compiled in the database http://193.219.168.19/ phpsql; later they were exported in the Microsoft Excel 2000 file. The collected answers were transferred into the SPSS 21, by means of which the data matrix was formed and calculations have been performed. The security against abuses that could distort the research data.

\section{Results}

In the research 1,231 respondents representing 21 professional activity fields, which were distinguished referring to the Classification of Economic Activities, took part. The questionnaire presented 25 fields of professional activity; however, the sample involved 21 . The respondents, who searched for the information about mobbing phenomenon in the website, took part in the survey voluntarily. Out of 1,231 respondents 867 respondents indicated that they had experienced mobbing. It has been indicated that other 364 participants of the survey have experienced nagging and sneering (referring to the criteria of sneering frequency, 
duration and action character). Thus it has been decided to present only the results of the survey on the employees who experienced mobbing.

Expression of mobbing in employees' relations in organizations of different activity type. In this research for the statistical data rationing the z-estimations of the standard normal distribution have been chosen. This measure, more precisely - the suitable scale (z-scale) is very handy and easily enough interpreted. The concrete questionnaire has been formed so that it would disclose negative issues - actions of nagging and sneering as well as the crisis of social work relations in the organization. Thus the high test estimation, that acquires positive meanings of the z-scale, shows the existing and stronger expressed actions of nagging and sneering in the employees' collective, and negative estimations respectively show the non- existing and weaker expressed such actions in the organization. For example, it is seen in Figure 1 that the expressions of the nagging and sneering actions most strongly manifest in the relations of the employees at the organizations of agriculture as well as mining and quarrying.

In this scale the mean of the rationing sample is always equal to 0 , and the standard deviation is equal to 1 . The testing results (i.e. - three dimensions according to all 45 primary features of the estimation of the nagging and sneering actions in the organization) are intercepted on the z-scale of the standard normal distributor in the diagram. In this scale the zero indicates the mean of the rationing sample. The dotted line shows the intercepted limits of the mean of the confidence interval, which fluctuate from minus 0.07 to plus 0.07 when the level of the statistical significance is $\alpha=0.05$.

\section{Fig. 1: The rating of the organizations in different activity fields according to the expression of nagging and sneering actions in the organization}

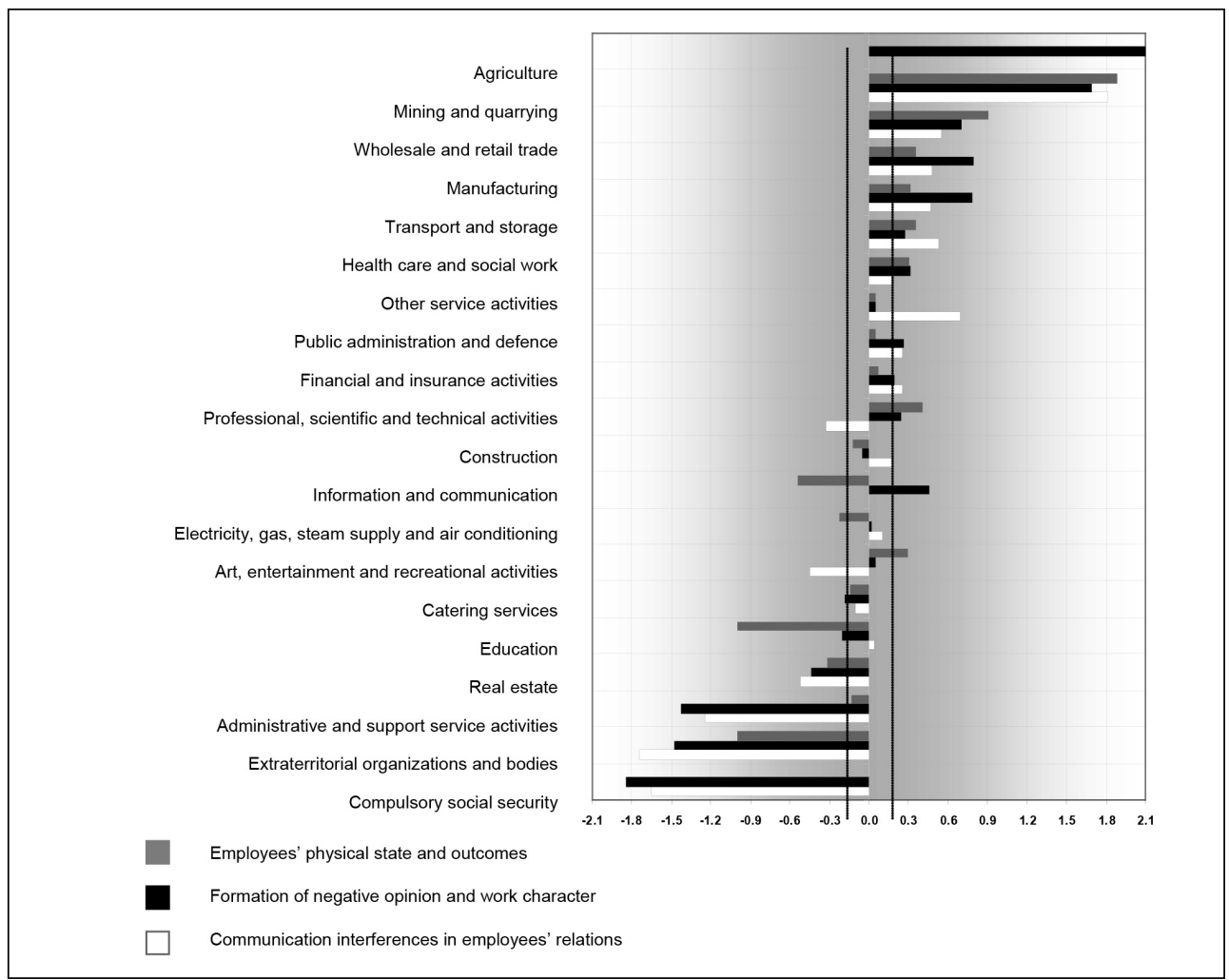


The rating starts with the organizations of 'Water supply, sewerage, waste management and regulation', 'Compulsory social security', 'Extraterritorial organizations and bodies', which expose the most favourably and which significantly transcended the organizations of other activity fields as well as the crisis features in which are expressed the most weakly and finishes with the organizations of 'Agriculture' and 'Mining and quarrying', in which the crisis features of the nagging and sneering actions have been expressed relatively the most strongly. The estimations of most organizations go beyond the limit of the confidence interval of the rationing sample mean and significantly deviate to the field of favourable or unfavourable estimations. There are only two organizations of 'Information and communication' and 'Construction', the estimation of which holds within the inside of the confidence interval and conforms the so-called 'the golden mean'. It is not hard to observe that according to the manifestation of the nagging and sneering actions in the organization the balance is held - there are almost equal number of the organizations of the different activity fields, the estimations of which overreach the limits of the confidence interval and deviates to the field of unfavourable or favourable estimations. When inter-comparing the 'leading' and 'slow' organizations of the different activity fields according to the manifestation of the nagging and sneering actions, it is evident that the difference of the integrated estimations reaches even 3.8 of the z-scale point and this makes almost four standard deviations. Such difference can be named as effectively evident and allows stating that the experience of the manifestation of the nagging and sneering actions in the organizations of the different profile should be estimated as very miscellaneous.

The previous researches on mobbing have already identified that business organizations most frequently face pressure, other phenomena humiliating human dignity; here mobbing has been stronger expressed than in organizations of public sector. Figure 2 presents the group estimations of the dimensions of the nagging and sneering actions in the main organizations, which have been intercepted according to the rating.

The data presented in Figure 2 visibly show that according to the expression of the nagging and sneering actions in the organization the organizations of private sector, the estimation of which is positive almost in all dimensions

\section{Fig. 2: The estimation of the nagging and sneering actions in the different
organizations}

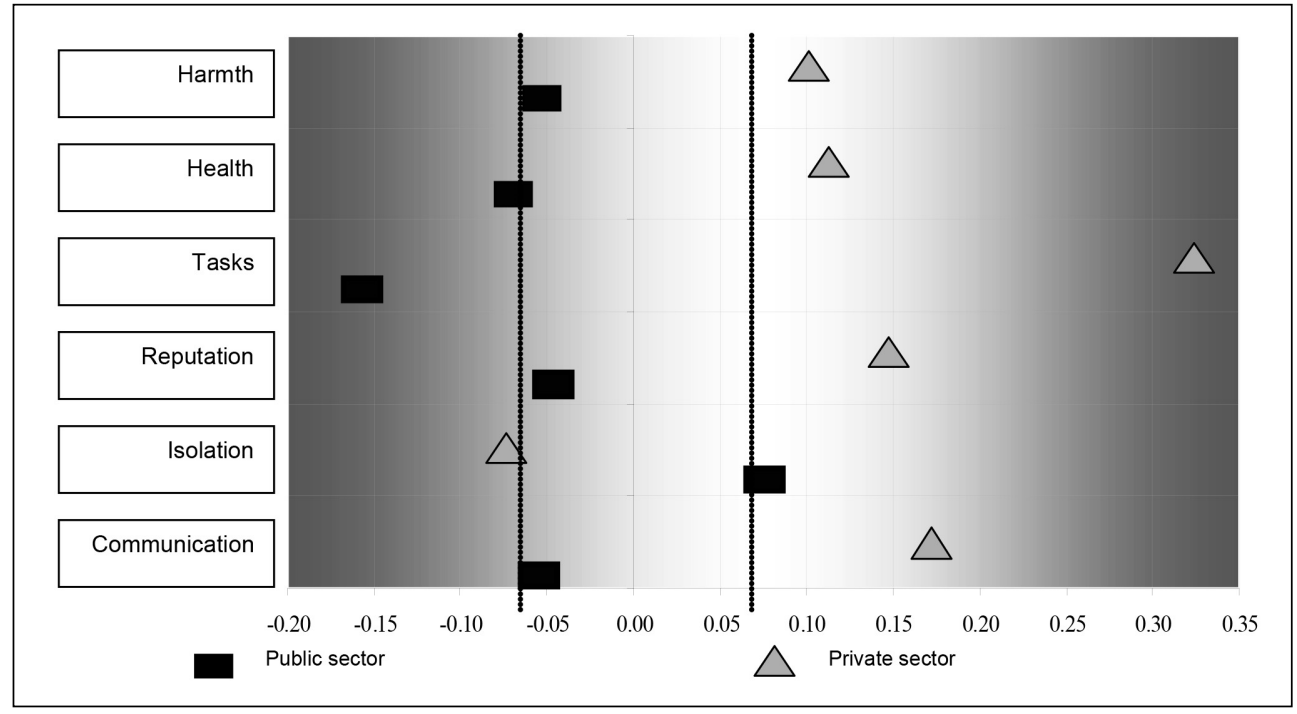


and passes the upper limit of the confidence interval, 'lead'. The diagram clearly shows that the group estimation of almost all organizations of public sector diverges to the field of negative estimations and drops below the bottom limit of the confidence interval. The greatest difference between the estimation of the organizations of public sector and the analogous estimation of the organizations of private sector has been identified according to the dimension of tasks and it reaches 0.48 of the $z$-scale point; and this makes almost half of the standard deviation. Thus the organizations of public sector better manage with the formation of negative opinion and work performance character than the organizations of private sector, to which these are the hardest problems. However, the organizations of public sector much more frequently than the organizations of private sector face the communication interferences in the employees' relations, particularly - isolation; however, according to this dimension the difference of the estimations is not so evident and does not reach a fifth of the standard deviation ( 0.14 of the z-scale point).

When interpreting the data, the outliersmeasure approach is applied. According to the main testing results the table of the statistical outliers is formed (see Table 1). The enlarged attention is always paid to what might strongly deviate from the mean (the norm). The statistical outlier shows that the organization of the particular activity type significantly deviates from the norm due to its achievements. In other words, in most organizations the deviation from analogous achievements to better or worse side takes place.

The length of the confidence interval of most means is rather little due to big enough rationing sample. It reaches $0.14 \mathrm{z}$-scale items when the maximum tolerance is 5 percent. The values diverging from the rating mean by 0.50 z-scale item are treated as statistical outliers in this research.

So far the expression of nagging and sneering action in organizations of different activity type has been estimated and compared only according to the consolidated test value. It integrates primary features of the manifestation of the nagging and sneering actions. As it has been mentioned, the primary features according to the test methodology have been integrated into six dimensions. It is also meaningful to find out how the above-mentioned six dimensions manifest in the organizations of different activity type. It is very important to know what particular actions of nagging and sneering and how strong they are expressed in the organization of different activity type. Tab. 1 reflects the results of such inspection. It presents the estimations of the organizations of every different type according to all six dimensions of the actions of nagging and sneering.

Table 2 shows that the nagging and sneering actions are the most weakly expressed in the organizations of 'Compulsory social security'. At first sight the table repeats the result, which has been reflected in the diagram of the rating of the organizations of different activity fields (see Fig. 1). However, the table data are more explicit. They show that in the context of these research results actually leading organizations of 'Extraterritorial organizations and bodies are on the top not according to all features. According to such important feature as 'Employees' physical state and outcomes' the organizations of such type hold only middle positions. In this viewpoint it is evidently passed by not only the leading organizations' activity type of 'Compulsory social security' but also by the organizations of 'Real estate' or 'Electricity, gas, steam supply and air conditioning'. Another opinion of the employees of the leading organization of 'Water supply, sewerage, waste management and regulation' has not been expressed on this aspect at all. The table also shows that such very unfavourable phenomenon as communication interferences in employees' relations that sharpens communication problems in the employees' collective is most common in the organizations of 'Mining and quarrying' and 'Public administration and defence'. It is necessary to note that in the organizations of 'Manufacturing' the crisis features of the actions of the negative opinion formation and work character, related to reputation and tasks, strongly manifest. Thus the application of the method of statistical outliers enables to identify and fix those undesirable cases of the rudiments of nagging and sneering actions.

In this research it has been decided not to restrict only by parameters of descriptive statistics and to perform the analysis referring to the multidimensional statistical method particularly the MDS-model (Multidimensional scaling). The model involved two dimensions the $z$-value and the variation size. So the model 


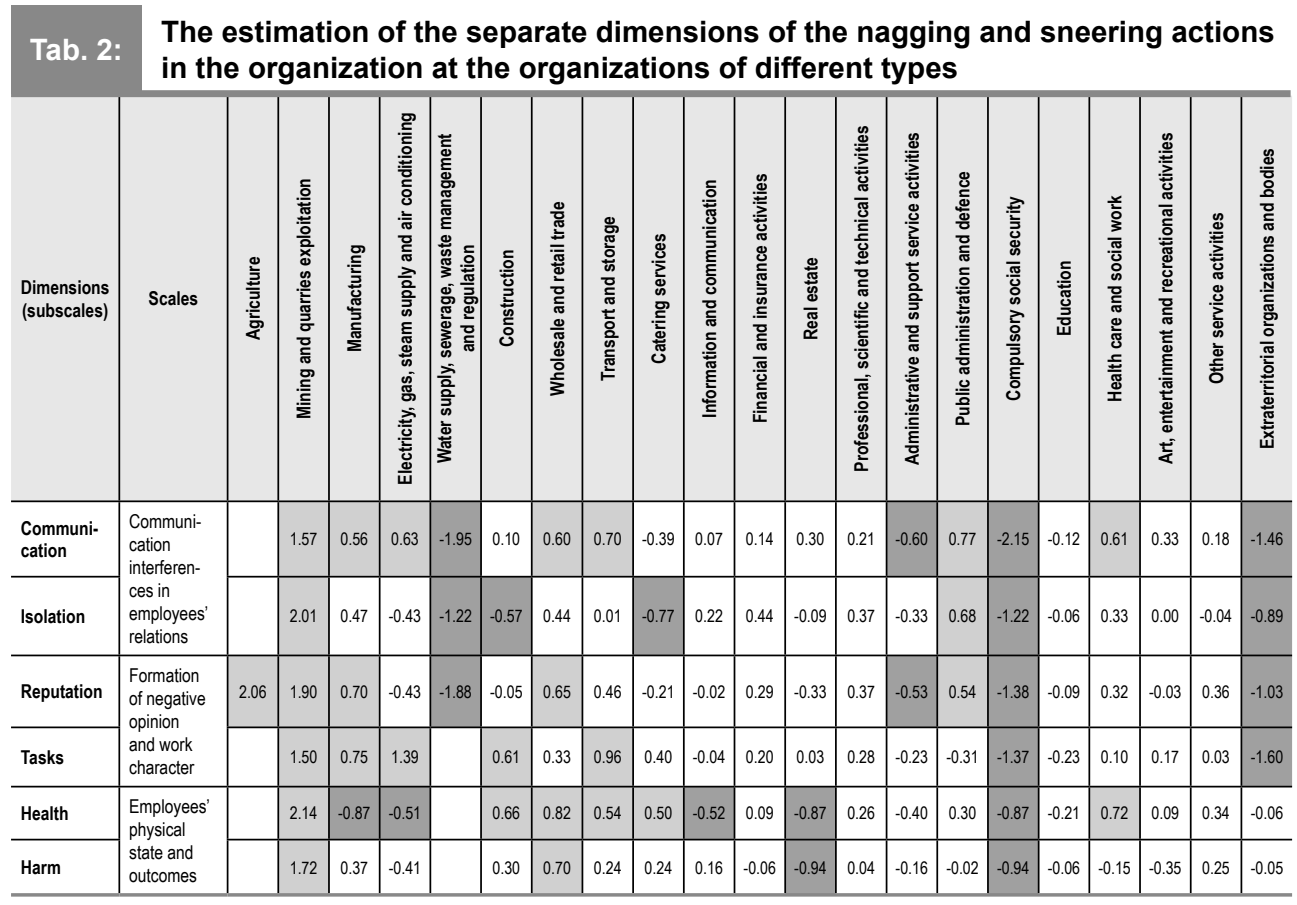

Source: own

Note: The standard z-estimations were used for rationing. The statistical outliers are marked in tones. The limit of the statistical outlier - is 0.5 of the z-estimation (i.e. 0.5 of the standard deviation). The negative statistical outliers are marked in the dark tone, the positive statistical outliers are marked in the lighter tone. The mean of the rationing sample is equal to 0 .

\section{MARKING:}

\begin{tabular}{l|l}
$z<-0.5$ & Deviation to the field of favourable estimation. \\
$z>0.5$ & Deviation to the field of unfavourable estimation.
\end{tabular}

has considered two issues - the expression of the actions of nagging and sneering (relatively higher or lower nagging and sneering being experienced) and the homogeneity of the opinion about the above-mentioned parameter within an organization (expression profile). The distances have been calculated referring to the data matrix; the chosen measure of the distance - the Euclid distance.

The levels of the mobbing expression have been identified; they show: where mobbing is expressed the most weakly; where mobbing expression is less than moderate level; where mobbing is expressed moderately; where mobbing expression is higher than moderate and strongly expressed mobbing in employees' relations.
The calculations of the MDS modelling are presented in Tables 3 and 4 . The larger negative $z$ value, the weaker mobbing is and vice versa - the larger positive $z$ value, the more active mobbing expressions is the professional activity field being analyzed. In Tables 3 and 4 the reflected percentage of approval shows the mobbing expression according to three scales. It is evident that the differences are vivid and significant enough. The MDS modelling presents the means, which show the generalized intensity of mobbing expression. According to all three scales mobbing is the most weakly expressed in the field of compulsory health insurance, which belongs to public sector. Among organizations of private sector less than moderate level mobbing expression 


\section{Ekonomika a management}

\section{Tab. 3: The weakest and very weak expression of mobbing}

\begin{tabular}{|c|c|c|c|c|c|}
\hline $\begin{array}{l}\text { Expression } \\
\text { of mobbing }\end{array}$ & \multicolumn{2}{|c|}{ Mobbing is expressed most weakly* } & \multicolumn{3}{|c|}{ The mobbing expression is lower than average level ${ }^{\star \star}$} \\
\hline Activities & Water supply & $\begin{array}{c}\text { Compulsory } \\
\text { social security }\end{array}$ & $\begin{array}{c}\text { Extraterritorial } \\
\text { organizations and } \\
\text { bodies }\end{array}$ & $\begin{array}{l}\text { Administrative and } \\
\text { support service } \\
\text { activities }\end{array}$ & Real estate \\
\hline $\begin{array}{l}\text { Communication } \\
\text { interferences } \\
\text { in employees' } \\
\text { relations }\end{array}$ & -1.65 & -1.74 & -1.24 & -0.52 & 0.04 \\
\hline $\begin{array}{l}\text { Formation } \\
\text { of negative } \\
\text { opinion and work } \\
\text { character }\end{array}$ & -1.85 & -1.48 & -1.42 & -0.44 & -0.21 \\
\hline $\begin{array}{l}\text { Employees' } \\
\text { physical state } \\
\text { and outcomes }\end{array}$ & & -1.00 & -0.14 & -0.31 & -1.00 \\
\hline Mean & -1.75 & -1.41 & -0.93 & -0.42 & -0.39 \\
\hline
\end{tabular}

* mobbing is expressed most weakly $\bigcirc$

** the mobbing expression is lower than average level $\bigcirc$

\section{Tab. 4: The strongest and very strong expression of mobbing}

\begin{tabular}{|c|c|c|c|c|c|c|c|c|}
\hline $\begin{array}{l}\text { Expression } \\
\text { of mobbing }\end{array}$ & \multicolumn{6}{|c|}{ The expression of mobbing is higher than moderate ${ }^{*}$} & \multicolumn{2}{|c|}{$\begin{array}{l}\text { Mobbing is strongly expressed } \\
\text { in employees' relations }{ }^{* *}\end{array}$} \\
\hline Activities & $\begin{array}{l}\text { Public admi- } \\
\text { nistration and } \\
\text { defence }\end{array}$ & $\begin{array}{l}\text { Other service } \\
\text { activities }\end{array}$ & $\begin{array}{l}\text { Health care and } \\
\text { social work }\end{array}$ & $\begin{array}{l}\text { Transport and } \\
\text { storage }\end{array}$ & Manufacturing & $\begin{array}{c}\text { Wholesale } \\
\text { and retail } \\
\text { trade }\end{array}$ & $\begin{array}{l}\text { Mining and } \\
\text { quarries } \\
\text { exploitation }\end{array}$ & Agriculture \\
\hline $\begin{array}{l}\text { Communication } \\
\text { interferences } \\
\text { in employees' } \\
\text { relations }\end{array}$ & 0.69 & 0.18 & 0.53 & 0.47 & 0.47 & 0.56 & 1.82 & \\
\hline $\begin{array}{l}\text { Formation of } \\
\text { negative opinion } \\
\text { and work } \\
\text { character }\end{array}$ & 0.06 & 0.32 & 0.28 & 0.78 & 0.79 & 0.70 & 1.69 & 2.10 \\
\hline $\begin{array}{l}\text { Employees' } \\
\text { physical state } \\
\text { and outcomes }\end{array}$ & 0.05 & 0.30 & 0.36 & 0.31 & 0.35 & 0.91 & 1.88 & \\
\hline Mean & 0.27 & 0.27 & 0.39 & 0.52 & 0.54 & 0.72 & 1.80 & 2.10 \\
\hline
\end{tabular}

* the expression of mobbing is higher than moderate

** mobbing is strongly expressed in employees' relations 
is observed in the organizations functioning in the field real estate operations, where attention should be paid to physical state of employees and its outcomes.

According to three scales mobbing is strongly expressed in the field of mining and quarrying. In the context of higher than moderate mobbing expression (private sector) the attention should be paid to trade, manufacturing as well as transport and storage activities. The estimations of the field of people health care and social work could have been influenced by mobbing intensity in private sector; however, further researches should be performed in order to verify or deny the premise.

The results of the MDS modelling are presented in Figure 3.

\section{Fig. 3: MDS model with the complete structure of the features}

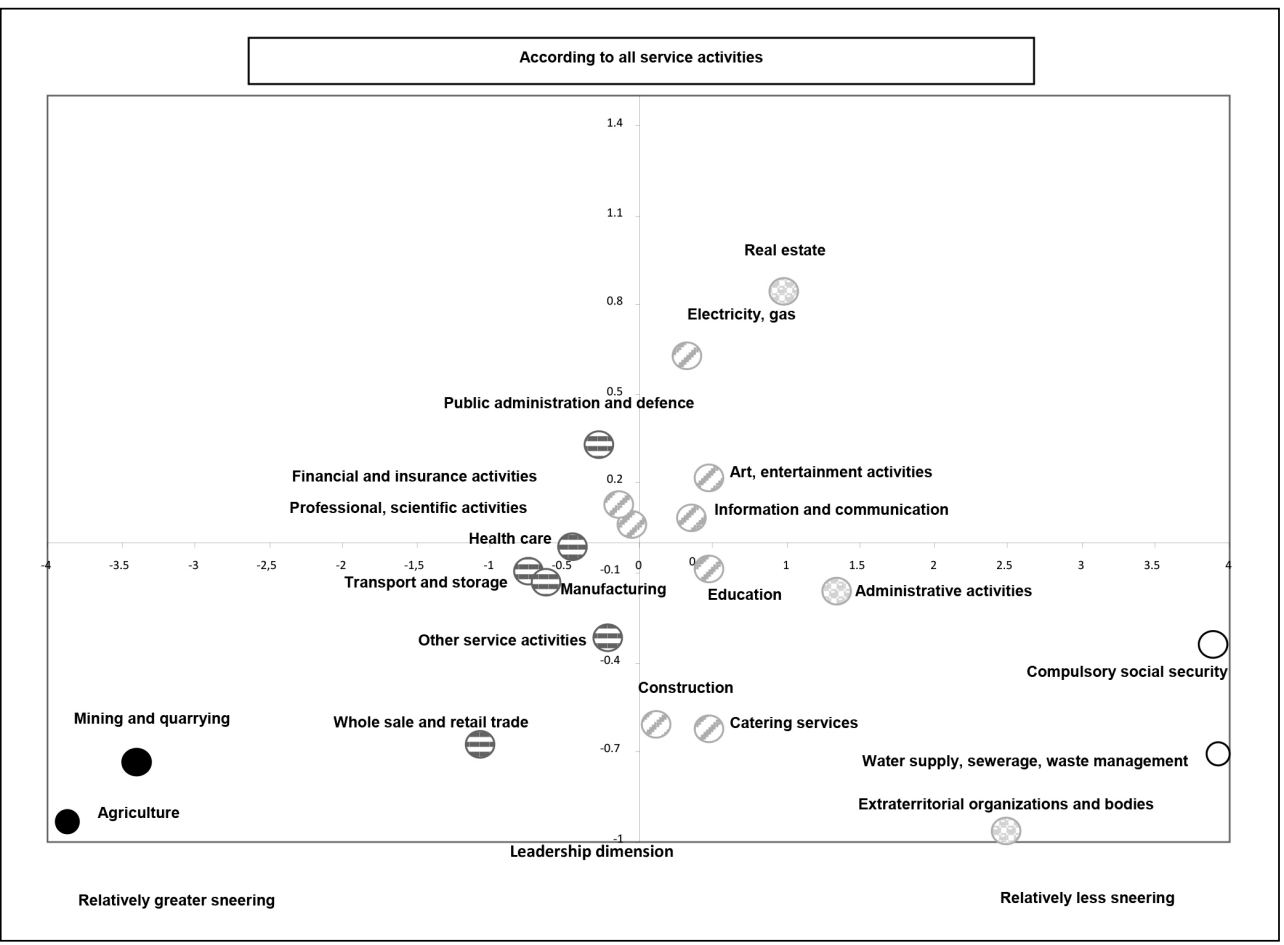

Source: own

The following levels of mobbing expression have been distinguished, they show where:

mobbing is expressed most weakly

the mobbing expression is lower than average level

1) mobbing is moderately expressed

三 the expression of mobbing is higher than moderate

mobbing is strongly expressed in employees' relations 
It should be noted that the MDS model is so-called exploratory method, and its result is acceptable if it is possible to be meaningfully interpreted. The first dimension (Axis $X$ ) can be relatively defined as the dimension of the strength of the expression of nagging and sneering being experienced; the left side of the map presents the types of the organizations, which distinguish in relatively higher nagging and sneering. In the right side the positions are occupied by the organizations, which distinguish in relatively lower nagging and sneering. The types of the organizations, which distinguish in non-homogenous estimation of the actions of nagging and sneering, are focused in the top of the map; and the types of the organizations, in which the opinion about the actions of nagging and sneering disperses relatively less and is more homogeneous, are focused in the bottom. Thus the second dimension (Axis $\mathrm{Y}$ ) denotes the homogeneity of the opinion about the expression of the actions of nagging and sneering. It is symptomatic that in the case of the MDS modelling the rating of the organizations' types according to the expression of the actions of nagging and sneering is once more proved; here the marginal positions on the left and the right of the map (according to the dimension of relatively higher / lower nagging and sneering) and the middle positions according to Axis $Y$ (the dimension of the estimations' homogeneity) are occupied by the organizations of the same types as in the general rating.

\section{Conclusions}

The research has shown that the situation is the most favourable in the following fields of the activities of public sector organizations: 'Water supply, sewerage, waste management and regulation', 'Compulsory social security', 'Extraterritorial organizations and bodies'. In the organizations of 'Agriculture' and 'Mining and quarrying' the crisis features have been expressed relatively most strongly.

The previous researches performed in Lithuania have been essentially confirmed by intensive enough expression of mobbing in the fields of education, health care. The estimates of most organizations step over the limit of confidence interval of normality sample mean and significantly deviate to the field of favourable or unfavourable estimations. The estimate of the organizations in the activity fields of 'Information and communication' and 'Construction' hold within the confidence interval.

According to the acceptation of attack in different organizations, the certain balance is noticed - the same number of the organizations of different activity fields, the estimations of which go beyond the limits of the confidence interval and deviates to the field of unfavourable or favourable estimations. When inter-comparing the relatively 'leading' and 'slow' organizations of different activity fields according to the expression of the nagging and sneering actions, it is evident that the difference of integrated estimations reaches even 3.8 of the z-scale point and this makes almost four standard deviations.

Such difference can be named as effectively evident and it allows stating that the experience of the manifestation of the nagging and sneering actions in the organizations of the different profile should be estimated as very miscellaneous.

The research has confirmed the results of the previous researches performed in Lithuania, that is, according to the expression of the nagging and sneering actions in the organization, the organizations of private sector, where the estimation exceeds the upper of the confidence interval almost in all dimensions, significantly distinguishes.

The nagging and sneering actions have been expressed the most weakly at the organizations of 'Compulsory social security'. The problem of the communication in the employees' interrelations becomes evident in the organizations of 'Mining and quarrying' as well as 'Public administration and defence'. It is necessary to point out that in the organizations of 'Manufacturing' the features of the crisis in the formation of negative opinion and work character actions related to reputation and tasks strongly manifest.

Leymann has defined mobbing as attacks, which happen not more infrequently than twice per week and last not less than half a year. However, it is possible to draw the premise that such purely statistical distribution is not axiomatic because psychosomatic reactions of people are different; thus employees can feel mobbing outcomes earlier than in half a year or suffer them for long years. It is necessary to estimate the democratic, pluralistic tradition and society knowledge about negative aspects of the mobbing behaviour (discriminating) 
and its tolerance. The societies that have outlived the system of the totalitarian initiative, oppression that humiliates human dignity and value levelling feel fears and distrustfulness; this also impedes research and practical work. When performing researches, some mobbing victims might not formally get into the group of the people being surveyed on mobbing though they can experience all related outcomes; thus the statistical expression can reflect the real situation not quite precisely. In other words, it should not be ignored that mobbing can be much more intensive than results of researches show. The researches performed in different countries show that the cohesion not only between demographic but also between social-cultural aspects, which vary subject to the culture of country's organization management that could be interpreted as measure of management culture development, exists. Tambur and Vadi [32] emphasized the transition period of mobbing institutionalization in states' statute-books; however, the problem of mobbing legal definition exists in the leading economics as well.

Though mobbing most frequently gets into the scope of psychological researches, it is the important problem of managerial culture as corporate culture component as well.

The research results have confirmed the formulated hypothesis that mobbing is the relevant managerial problem, the expression of which is more intensive in organizations of the private sector. This is underlined by the following fields sensitive to management: tasks, communication, harm and others. The main reasons - the historical-cultural heritage, which greatly influences management culture, as well as the historical traditions of business organizations' property and management.

\section{Discussion}

Already in the ninth decade of the last century the initiatives of M. Gorbachev 'perestroika' (reorganization) legitimized business potential, the initial capital was accumulated, and initiative citizens became owners of newly created business. This period, involving the processes of the private initiative induced by the restoration of the independence, is defined as 'wild capitalism', which the state of Lithuania together with other European countries experienced in the end of the 19th century and in the beginning of the 20th century till the occupation; however, subsequent repressions did not allow natural developing of national entrepreneurship culture.

After the restoration of the independence the decisive role was played not by org-managerial competence but by the ability to raise the capital in privatization processes; thus a lot of initiative people but without managerial education who in personnel management followed 'general understanding', 'competition' and 'strategies of survival', according to which the strongest wins. Differently than in private sector (except leading companies of national and foreign capital), in public sector the requirements for managerial competence are formulated by the state regulation mechanisms, which are supported by the programmes financed by the EU structural funds.

\section{References}

[1] ALTINTAŞ, V., YILMAZ, Y., ÇETINEL, F. Mobbing in accomodation businesses: sample of Antalya. E-Journal of New World Sciences Academy. 2011, Vol. 6, Iss. 4, pp. 439-454. ISSN 1306-3111.

[2] APPELBAUM, S.H., SEMERJIAN, G., MOHAN, K. Workplace bullying: consequences, causes and controls. Industrial and Commercial Training. 2012, Vol. 44, Iss. 6 , pp. 337-344. ISSN 0019-7858. DOI: 10.1108/00197851211254770.

[3] BROTHERIDGE, C.M., LEE, R.T., POWER, J.L. Am I my own worst enemy? The experiences of bullying targets who are also aggressors. Career Development International. 2012, Vol. 17, Iss. 4, pp. 358-374. ISSN 13620436. DOI: $10.1108 / 13620431211255833$.

[4] BULTENA, C.D. Bushwhacked at work: a comparative analysis of mobbing and bullying at work. Proceedings of ASBBS. 2008, Vol. 15, Iss. 1, pp. 652-666. ISSN 1934-0583.

[5] CAPORALE, L., PALESE,A., BORTOLUZZI, $G$. The leadership style as a mitigator of the insurgence of mobbing risk. Results from an empirical research on Italian nurses. Giornale Italiano di Medicina del Lavoro ed Ergonomia. 2012, Vol. 34, Iss. 1 Suppl A, pp. A17-24. ISSN 1592-7830.

[6] CARNERO, M.A., MARTINEZ, B. Economic and health consequences of the initial stage of Mobbing: the Spanish case. Presentations for the Faculty of Business \& Law. Edith Cowan University, Perth, Western Australia, 2005. 
[7] CARRETERO, D.N., GIL-MONTE, P.R., LUCIANO, D.J. V. Antecedents and consequences of workplace bullying: a longitudinal analysis with a structural equation model. Psicothema. 2011, Vol. 23, Iss. 4, pp. 617-623. ISSN 0214-9915.

[8] CASIMIR, G., et al. Psychosomatic model of workplace bullying: Australian and Ugandan schoolteachers. Employee Relations. 2012, Vol. 34, pp. 411-428. ISSN 0142-5455.

[9] CEVIK, A.R., et al. Levels of mobbing perception among nurses in Eastern Turkey. International Nursing Review. 2012, Vol. 59, Iss. 3, pp. 402-408. ISSN 1466-7657. DOI: 10.1111/j.1466-7657.2012.00974.x.

[10] CORNAMUSAZ, A. Mobbing and unfair dismissal. The responsibility of the employer. Krankenpflege. Soins Infirmiers. 2011, Vol. 104, Iss. 3, pp. 32. ISSN 0253-0465.

[11] CORNAMUSAZ, A. Mobbing. Mostly the victim leaves, not the perpetrator. Krankenpflege. Soins Infirmiers. 2011, Vol. 104, Iss. 11, pp. 32. ISSN 0253-0465.

[12] DIKMETAS, E., TOP, M., ERGIN, G. An examination of mobbing and burnout of residents. Türk Psikiyatri Dergisi - Turkish Journal of Psychiatry. 2011, Vol. 22, Iss. 3, pp. 137-149. ISSN 1300-2163.

[13] DOMINGUEZ, F.J.M., et al. Behavioral types in relation to burnout, mobbing, personality, and adaptation of self-conduct in health care workers. Atencion Primaria. 2012, Vol. 45, Iss. 4, pp. 199-207. ISSN 0212-6567. DOI: 10.1016/j.aprim.2012.11.002.

[14] FARIA, J.R., MIXON, Jr. F.G., SALTERC, S.P. An economic model of workplace mobbing in academe. Economics of Education Review. 2012, Vol. 31, Iss. 5, pp. 720-726. ISSN 0272-7757.

[15] FENGA, C., et al. Mobbing: between personality traits and organizational-managerial characteristics of the occupational environment. Giornale Italiano di Medicina del Lavoro ed Ergonomia. 2012, Vol. 34, Iss. 1 Suppl A, pp. A11-16. ISSN 1592-7830.

[16] FIGUEIREDO-FERRAZ, H., et al. Influence of some psychosocial factors on mobbing and its consequences among employees working with people with intellectual disabilities. Journal of Applied Research of Intellectual Disabilities. 2012, Vol. 25, Iss. 5, pp. 455-463. ISSN 14683148. DOI: 10.1111/j.1468-3148.2012.00687.x. [17] GRUŽEVSKIS, B., OKUNEVIČIŪTĖNEVERAUSKIENĖ, L., POCIUS, A. Nelegalaus darbo, teisés aktu, reglamentuojančiu darbo santykius, pažeidimu, darbdaviu atstovy grasinimy ar kitokio psichologinio poveikio itakos darbuotoju darbo rezultatams bei saugai ir sveikatai tyrimas-The research of the impact of illegal work, breach of legislation regulating labour relations, threats of employers' representatives and other psychological influence on employees' performance, safety and health. Vilnius: Darbo ir socialiniu tyrimy institutas-Institute for Labour and Social Research, 2004.

[18] JASINSKAS, E., et al. Influence of employees evaluation on organisational learning at leisure \& sports clubs. $E+M$ Ekonomie a Management. 2015, Vol. 18, Iss. 3, pp. 41-49. ISSN 1212-3609. DOI: 10.15240/ tul/001/2015-3-004.

[19] KOSTEV, K., et al. Risk of psychiatric and neurological diseases in patients with workplace mobbing experience in Germany: a retrospective database analysis. GMS German Medical Science. 2014, Vol. 12, pp. 1-9. ISSN 1612-3174. DOI: 10.3205/000195.

[20] LAAKSONEN, E., et al. Economic difficulties and common mental disorders among Finnish and British white-collar employees: the contribution of social and behavioral factors. Journal of Epidemiology and Community Health. 2009, Vol. 63, Iss. 6, pp. 439-446. ISSN 1470-2738. DOI: 10.1136/jech.2008.077198.

[21] LEON-PEREZ, J.M., et al. Identifying victims of workplace bullying by integrating traditional estimation approaches into a latent class cluster model. Journal of Interpersonal Violence. 2014, Vol. 29, Iss. 7, pp. 1155-1177. ISSN 0886-2605. DOI: 10.1177/0886260513506280.

[22] LEYMANN, H. Mobbing and Psychological Terror at workplaces. Violence and Victims. 1990, Vol. 5, Iss. 2, pp. 119-126. ISSN 0886-6708.

[23] LEYMANN, $H$. The content and development of mobbing at work. European Journal of Work and Organisational Psychology. 1996, Vol. 5, Iss. 2, pp. 165-184. ISSN 1359432X. DOI: 10.1080/13594329608414853.

[24] MALINAUSKIENĖ, V., OBELENIS, V., ŠOPAGIENĖ, D. Psychological terror at work and cardiovascular diseases among teachers. Acta Medica Lituanica. 2005, Vol. 12, Iss. 2, pp. 20-25. ISSN 1392-0138. DOI: 10.6001/ actamedica.v12i2.235.

[25] NIEDHAMMER, I., et al. Economic activities and occupations at high risk for workplace bullying: results from a largescale 
cross-sectional survey in the general working population in France. International Archives of Occupational and Environmental Health. 2007, Vol. 80, Iss. 4, pp. 346-353. ISSN 0340-0131. DOI: $10.1007 / \mathrm{s} 00420-006-0139-y$.

[26] NIEDL, K. Mobbing and wellbeing: economic and personnel development implication. European Journal of Work and Organizational Psychology. 1996, Vol. 5, Iss. 2, pp. 239-249. ISSN 1359-432X. DOI: 10.1080/13594329608414857.

[27] OFLUOGLU, G., SOMUNOGLU, S. Cases of mobbing activities as commonly seen in the healthcare sector in the world and in Turkey. Hospital Topics. 2012, Vol. 90, Iss. 4, pp. 98-103. ISSN 0018-5868. DOI: 10.1080/00185868.2012.737754.

[28] PAI, H.C., LEE, S. Risk factors for workplace violence in clinical registered nurses in Taiwan. Journal of Clinical Nursing. 2011, Vol. 20, Iss. 9-10, pp. 1405-1412. ISSN 13652702. DOI: 10.1111/j.1365-2702.2010.03650.x. [29] SALIN, D. Ways of explaining workplace bullying: a review of enabling, motivating and precipitating structures and processes in the work environment. Human Relations. 2003, Vol. 56, Iss. 10, pp. 1213-1232. ISSN 0018-7267. [30] SĄLYGA, J., MALAKAUSKIENE், R., JONUTYTÉ, I. Lietuvos jūrininku patiriamo psichologinio teroro ir fizinès sveikatos ryšys. Sveikatos mokslai-Health Sciences. 2008, Vol. 2, Iss. 56, pp. 1613-1616. ISSN 1392-6373. [31] SOLIANIK, R., et al. Intermittent wholebody cold immersion induces similar thermal stress but different motor and cognitive responses between males and females. Cryobiology. 2014, Vol. 69, Iss. 2, pp. 323332. ISSN 0011-2240. DOI: 10.1016/j. cryobiol.2014.08.007.

[32] TAMBUR, M., VADI, M. Workplace bullying and organizational culture in a post-transitional country. International Journal of Manpower. 2012, Vol. 33, Iss. 7, pp. 754-768. ISSN 01437720. DOI: $10.1108 / 01437721211268302$.

[33] TESTA, C. Crisis - What crisis? The jobless society and Italian cinema in the early 2000s. Forum Italicum: A Journal of Italian Studies. 2013, Vol. 47, Iss. 1, pp. 126-149. ISSN 0014-5858. DOI: 10.1177/0014585813479884. [34] TOMIĆ, M.A. Mobbing: the incidence of mobbing activities and differences regarding workplace and gender. Megatrend Review. 2012, Vol. 9, Iss. 1, pp. 243-252. ISSN 18203159.
[35] TONINI, S., et al. Work-related stress and mobbing: case series and gender differences. Giornale Italiano di Medicina del Lavoro ed Ergonomia. 2011, Vol. 33, Iss. 4, pp. 409-413. ISSN 1592-7830.

[36] TONINI, S., et al. Work-related stress and bullying: gender differences and forensic medicine issues in the diagnostic procedure. Journal of Occupational Medicine and Toxicology. 2011, Vol. 6, Iss. 29, pp. 1-6. ISSN 1745-6673. DOI: 10.1186/1745-6673-6-29.

[37] TOO, L., HARVEY, M. „TOXIC“ workplaces: the negative interface between the physical and social environments. Journal of Corporate Real Estate. 2012, Vol. 14, Iss. 3, pp. 171-181. ISSN 1463-001X.

[38] VASILJEVAS, A., PUČĖTAITĖ, R. Socialinès imoniu atsakomybès ir efektyvaus žmogiškuju išteklių valdymo igyvendinimas dalykinès etikos priemonemis-Realization of corporate social responsibility and effective human resource management by ethics tools. Organizacijy vadyba: sisteminiai tyrimai-Management of Organizations: Systematic Research. 2005, Vol. 36, pp. 193-212. ISSN 1392-1142.

[39] VASILJEVIENĖ, N. Organizacijų etika kaip vadybos optimizavimo irankis-Organization ethics as the tool for management optimization. Ekonomika-Economics. 2004, Vol. 67, Iss. 2, pp. 131-144. ISSN 1392-1258.

[40] VVEINHARDT, J. The structurogram of the mobbing diagnostic model. Transformations in Business and Economics. 2011, Vol. 10, Iss. 2A(23A), pp. 317-333. ISSN 1648-4460.

[41] VVEINHARDT, J. Identification of the reliability of methodological characteristics of quality in the diagnostic instrument for mobbing as discrimination in employee relations on purpose to improve the climate in Lithuanian organisations. Transformations in Business and Economics. 2012, Vol. 11, Iss. 2(26), pp. 218232. ISSN 1648-4460.

[42] ZAPF, D. Emotion Work and Psychological Wellbeing. A Review of the Literature and some Conceptual Considerations. Human Resource Management Review. 2002, Vol. 12, Iss. 2, pp. 237-268. ISSN 1053-4822. DOI: 10.1016/ S1053-4822(02)00048-7.

[43] ZAPF, D., WARTH, K. Mobbing: Subtile Kriegsfuhrung am Arbeitsplatz. Psychologie Heute. 1997, Vol. 24, Iss. 8, pp. 28-29. ISSN 0340-1677.

[44] ŽUKAUSKAS, P., VVEINHARDT, J. The model of managerial intervention decisions 


\section{Ekonomika a management}

of mobbing as discrimination in employees' relations in seeking to improve organization climate. Engineering Economics. 2010, Vol. 21, Iss. 3, pp. 306-314. ISSN 1392-2785.

[45] ŽUKAUSKAS, P., VVEINHARDT, J. Mobbing diagnosis instrument: stages of construction, structure and connectedness of criteria. Journal of Business Economics and Management. 2011, Vol. 12, Iss. 2, pp. 400-416. ISSN 1611-1699. DOI: 10.3846/16111699.2011.575193. prof. Jolita Vveinhardt, Ph.D.

Lithuanian Sports University Institute of Sport Science and Innovations jolita.vveinhardt@gmail.com

prof. Dalia Štreimikienè, Ph.D. Lithuanian Sports University Institute of Sport Science and Innovations dalia.streimikiene@lsu.It 


\title{
THE INTENSITY OFTHE EXPRESSION OF MOBBING IN EMPLOYEES' RELATIONS AT LITHUANIAN ORGANIZATIONS
}

\author{
Jolita Vveinhardt, Dalia Štreimikienè
}

The authors present general review of the literature, present the results of the empirical research on the expression intensity of mobbing in employees' relations in organizations. The expression of mobbing in employees' relations has been identified in the organizations of different activity type. The expression of mobbing in employees' relations has been identified in the organizations of different activity type. When comparing organizations of private and public sectors, the tendency that the expression of mobbing is more intensive in the private sector, especially in economical activities of agriculture and mining as well as querying, manifests. The hypothesis that mobbing is not only psychological but also managerial problem has been confirmed; it is more relevant for organizations of the private sector in Lithuania. This is influenced by poorly developed management culture and the lack of managerial knowledge, which is characteristic for management personnel. Lithuania as well as other post-Soviet countries has not performed the researches on mobbing phenomenon broadly and deeply by emphasizing managerial reasons of the phenomenon. The researches on mobbing disclose the 'sensitive' areas, which influence the internal climate of national capital's organizations, the development of their competitiveness and the improvement of the corporate country investment climate. The originality of this research is presupposed not only by the fact that the situation in private and public sectors has been surveyed but also that it has been tried to identify the spread of mobbing among different fields of professional activity. In the case of this research 21 fields of professional activity have been included. During the research higher than medium expression of mobbing has been identified in the field of people health care and social work, which consist of the organizations of both public and private capital (in which more significant mobbing intensity has been identified) in Lithuanian context. It would be relevant to elaborate the research in striving to disclose differences in the culture of organizations' management.

Key Words: Mobbing, behaviour, conflict, employee behaviour, employee relations, interpersonal relations.

JEL Classification: M12, M14, M19.

DOI: 10.15240/tul/001/2015-4-004 